\title{
Isolation of Feline Adipose Tissue Derived Mesenchymal Stem Cells
}

\author{
Shazia Nissar ${ }^{*}$, Geetha Ramesh ${ }^{2}$, Sabiha Hayath Basha ${ }^{3}$, \\ C. Balachandran ${ }^{4}$ and V. Leela ${ }^{5}$ \\ ${ }^{1}$ Tamil Nadu Veterinary and Animal Sciences University, Madras Veterinary College, \\ Chennai- 600 007, India \\ ${ }^{2}$ Department of Veterinary Anatomy, ${ }^{3}$ Centre for Stem Cell Research and Regenerative \\ Medicine, ${ }^{4}$ Department of Veterinary Pathology, ${ }^{5}$ Department of Veterinary Physiology, \\ Tamil Nadu Veterinary and Animal Sciences University, Madras \\ Veterinary College, Chennai- 600 007, India \\ *Corresponding author
}

\section{A B S T R A C T}

\section{Keywords}

Stem cell, Adipose tissue, Feline, Isolation and Culture

Article Info

Accepted:

07 February 2018

Available Online:

10 March 2018
The omental adipose tissue was collected from, the animals undergone ovariohysterectomy surgical procedures. The samples were digested with 0.1 per cent $(\mathrm{W} / \mathrm{V})$ collagenase type I and transferred to a beaker with magnetic stirrer at $600 \mathrm{rpm}$ at $37^{\circ} \mathrm{C}$ for 30 minutes. The lesser time was given for enzymatic digestion as compared to other species. The viability of the cell was evaluated by trypan blue exclusion method using haematocytometer. Trypan blue had a high affinity to nuclear DNA, which traverse the membrane in a dead cell and dye it blue. The isolated cells were seeded at a density of $1 \times 10^{6}$ cells per T25 culture flask and incubated in $5 \mathrm{ml}$ of DMEM-HG at $37^{\circ} \mathrm{C}$ with 5 per cent $\mathrm{CO}_{2} .70-80$ per cent confluency was observed on day six and 100 percent confluency on day seven.

\section{Introduction}

Adipose tissue, as a stem cell source is ubiquitously available and has several advantages compared to other sources.

It is easily accessible in large quantities with minimal invasive harvesting procedure and the isolation of these Adipose-derived mesenchymal stem cells (AD-MSCs) yields a high amount of stem cells, which is essential for stem-cell-based therapies and tissue engineering. AD-MSCs are indeed multipotent somatic stem cells exhibiting growth kinetics, plasticity and proved to induce efficient tissue regeneration in several biomedical applications. Cultures of AD-MSCs were easier to generate because of their higher intrinsic proliferative rate and maintain their phenotypes. Hence, it is used for tissue engineering and regenerative medical applications (Bunnell et al., 2008).

\section{Materials and Methods}

\section{Collection of feline adipose tissue}

The feline omental adipose tissue, collected from healthy animals undergone surgeries of ovariectomy and ovariohysterectomy (Figure 
1). The sample was collection bottle which contained phosphate buffer saline (PBS) and processed within 30 minutes of collection.

Isolation of feline adipose derived mesenchymal stem cells (fAD-MSCs)

The weighed adipose tissue was rinsed with phosphate-buffered saline, to remove blood, small vessels and connective tissue. Cleaned adipose tissue was cut into small pieces by using sterile forceps and surgical blade. Samples were digested with 0.1 per cent (W/V) collagenase type I (SIGMA) and transferred to a beaker with magnetic stirrer and kept in stirrer with $600 \mathrm{rpm}$ at $37^{\circ} \mathrm{C}$ for 30 minutes (Kono et al., 2014).

After digestion stromal vascular fraction (SVF) was pipetted out and neutralized with equal volume of Dulbecco's modified Eagle medium-high glucose (DMEM-HG) with fetal bovine serum (FBS) and antibiotic solution and non-essential amino acids was added to it (Al Nbaheen et al., 2013).

Finally, it was centrifuged at $2500 \mathrm{rpm}$ for 10 minutes, supernatant was discarded and pellet was resuspended in $1 \mathrm{ml}$ of culture media to get cell suspension (Aliborzi et al., 2016) (Figure 2). Cell viability and total cell density were determined by 0.4 per cent Trypan blue exclusion test to check the viability of cells (Figure 3).

\section{Seeding of feline adipose derived mesenchymal stem cells}

Viable AD-MSCs from resuspended pellet were seeded at a density of $1 \times 10^{6}$ cells per T25 culture flask and incubated in $5 \mathrm{ml}$ of DMEM-HG at $37^{\circ} \mathrm{C}$ under 5 per cent $\mathrm{CO}_{2}$ in $\mathrm{CO}_{2}$ incubator (Beaulah et al., 2016) (Figure 4). The spent medium was replaced initially with fresh DMEM-HG after two days of seeding. Then fresh medium was added daily until the cells reached a confluency of 70- 80 per cent (Vieira et al., 2010).

Subculturing of feline adipose derived mesenchymal stem cells

After 70-80 per cent confluency the cells were detached from the culture flask by using 0.25 per cent trypsin / EDTA for 2 minutes at $37^{\circ} \mathrm{C}$. DMEM-HG containing 10 per cent fetal bovine serum (FBS) was added and cells were kept in refrigerator to stop the action of trypsin.

Then the cells were disaggregated by pipetting the medium into culture flask gently. Cell pellet was prepared by spinning the cell suspension at $1500 \mathrm{rpm}$ for 15 minutes.

Then the pellet was reconstituted with $1 \mathrm{ml}$ DMEM-HG and seeding density was maintained after counting the cells for subculturing.

Cells were passaged subsequently on reaching the confluency (Zahran et al., 2013)

\section{Results and Discussion}

\section{Source of fAD-MSCs}

In this study, the sterile omental adipose tissue was collected from healthy animals undergone surgeries of ovariectomy and ovariohysterectomy in line with the procedure followed by Webb et al., (2011) and Kono et al., (2014) in feline. In canine, adipose tissue was collected from inguinal fat, omental and subcutaneous fat (Neupane et al., 2008).

In human, the most common sites for collection of adipose tissue were subcutaneous fat and omental fat as per the finding of Marappagoundar et al., (2010), as they concluded that AD-MSCs from both the sites could be useful for regenerative medicine 


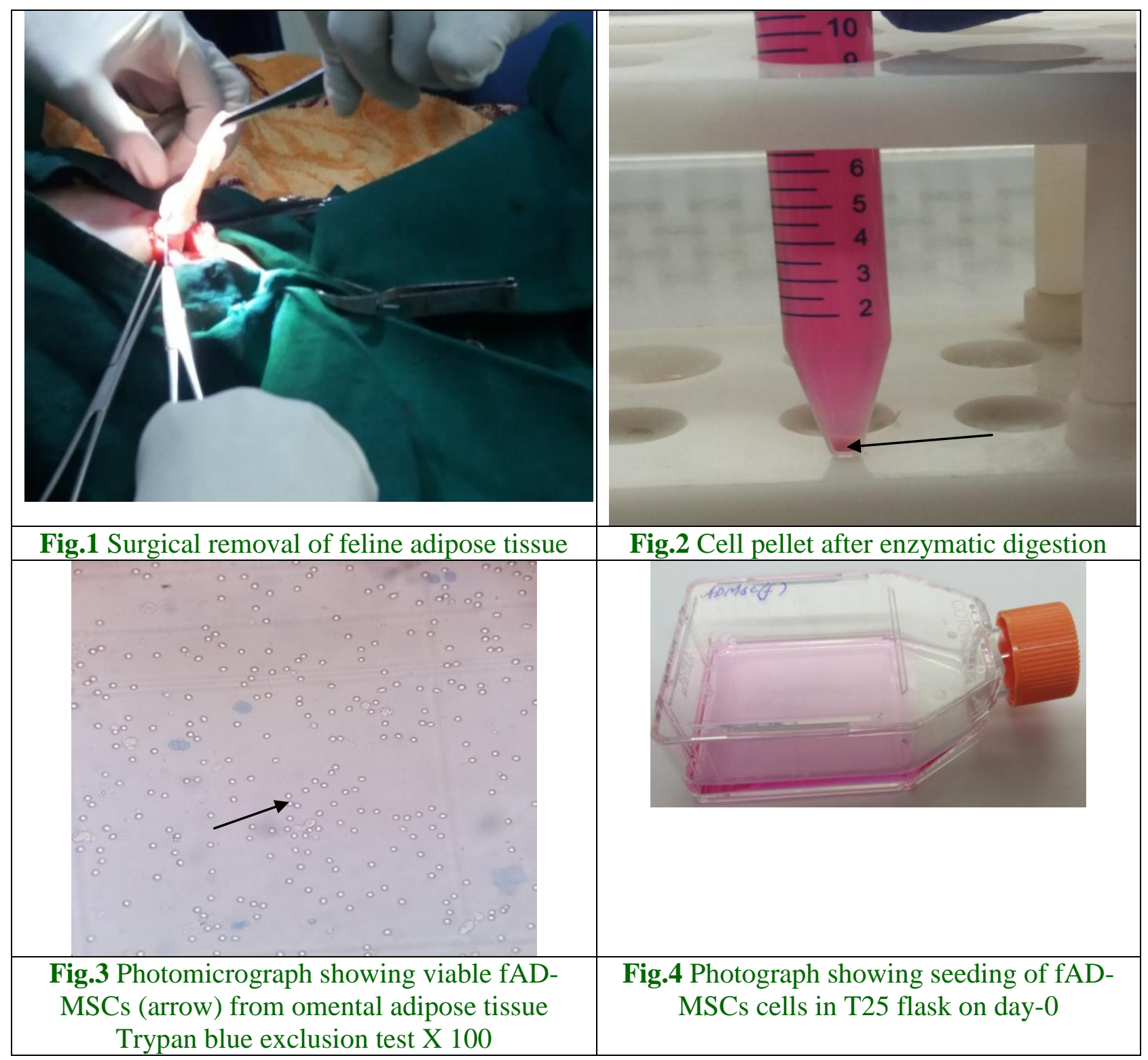

\section{Enzymatic digestion}

The feline adipose derived mesenchymal stem cells (fAD-MSCs) were processed and subjected to collagenase type I (0.1 per cent $\mathrm{W} / \mathrm{V})$ treatment for isolation of stromal vascular fraction (SVF) as followed by Webb et al., (2011) and Kono et al., (2014) in feline. The cell viability was confirmed by Trypan blue exclusion test. The live cells were observed with transparent cytoplasm and intact nucleus. The cytoplasms of dead cells were stained with trypan blue. In the present study, lesser time was given for enzymatic digestion as compared to other species, because feline adipose tissue was soft which might be due to less collagen fiber content. According to Hepsibha et al., (2011) AD-MSCs isolation from buffalo was processed by 0.1 per cent collagenase with 1 per cent bovine serum albumin (BSA). The yield of $\mathrm{AD}-\mathrm{MSC}$ was low when collagenase alone was used might be due to higher collagen fiber content in buffalo adipose tissue. In the present study, after enzymatic digestion, stromal vascular fraction (SVF) was pipetted out and neutralized with equal volume of DMEM-HG with fetal bovine serum and antibiotic solution and non-essential amino acids as described by 
Al-Nbaheen et al., (2013) in human. Than samples, was centrifuged at $2500 \mathrm{rpm}$ for 10 minutes, supernatant was discarded and pellet was resuspended in one $\mathrm{ml}$ of culture media to get cell suspension as reported by Aliborzi et al., (2016) in guinea pig.

\section{Culture and expansion}

\section{Seeding of fAD-MSCs}

Viable fAD-MSCs were seeded at a density of $1 \times 10^{6}$ cells per $T_{25}$ culture flask and incubated in $5 \mathrm{ml}$ of DMEM-HG at $37^{\circ} \mathrm{C}$ under 5 per cent $\mathrm{CO}_{2}$ as per Beaulah et al., (2017) in Madras Red Sheep. Density of mononuclear cells is one of the important factors to determine efficiency of MSCs in culture as this affects the adherence of MSCs, contamination by other cell types and initial growth of adhered MSCs as reported by Ikeba and Suzuki (2014). In the present study, the plastic adherence was observed after 24 hours which satisfied the first criteria of being mesenchymal stem cells proposed by Mesenchymal and Tissue Stem Cell Committee of the International society for Cellular Therapy (Dominici et al., 2006). Similar finding was observed by Webb et al., (2011) in feline. According to Beaulah et al., (2016) and Fadel et al., (2011), the plastic adherence of AD-MSC was observed after 24 hours in primary culture. Similarly in buffalo, adherence was noticed after 24 hours (Hepsibha et al., 2011). Whereas Ren et al., (2012) reported in rat and goat that adherence has been observed after two to four hours and Barberini et al., (2014) reported the adherence of AD-MSCs in 32 hours in equine.

The presence of non-adherent cells were removed from the primary culture after three days to get rid of contamination as it contained some dead cells. Since adipose tissue was highly vascularized, higher proportion of hematopoietic cells were seen. Frequent media change in first two days of initial culture had significant importance for maintenance of culture which is also reported by Deans and Moseley (2000). The spent medium was replaced initially with fresh of DMEM-HG after two days of seeding. Then fresh medium was added daily until the cells reached of 70- 80 per cent confluency in accordance with Vieira et al., (2010).

\section{Subculture of fAD-MSCS}

In the present study, the cultured cells from P0 on day seven post incubation with 100 per cent confluency were subjected to passage1. The cells were trypsinised and seeded into the new plates at 1:3 ratio for $\mathrm{P} 1$. On day two in $\mathrm{P} 1$, the cells started showing expansion with spindlelike morphology. On day three, the cells exhibited varied morphology such as stellate, triangular and polyhedral. The stellate cells were found to be more. On day five post incubation the cells attained about 60-70 per cent confluency at P1. According Beaulah et al., (2016) in Madras Red Sheep, subcutaneous and omental AD-MSCs took six days to reach same percentage in $\mathrm{P} 1$. The initial culture contained heterogeneous cell population with round and fibroblastic cell, upon culture, the number of rounded cell decreased and fibroblastic cells started increasing.

\section{References}

Aliborzi, G., A. Vahdati, D. Mehrabani and S.E. Hosseini, 2016. Isolation, characterization and growth kinetic comparison of bone marrow and adipose tissue mesenchymal stem cells of guinea pig. Inter. J. Stem Cells. 9(1): 115-123.

Al-Nbaheen, M., R. Vishnubalaji, D. Ali, A. Bouslimi, F. Al-Jassir, M. Megges, A. Prigione, J. Adjaye, M. Kassem and A. Aldahmash, 2013. Human Stromal (Mesenchymal) Stem Cells from Bone Marrow, Adipose Tissue and Skin Exhibit Differences in Molecular Phenotype and Differentiation Potential. Stem Cell Rev Rep., 9:32-43.

Barberini, J.D., P.P.F. Natalia, S.M. Mariana, M. Leandro, J.L. Amanda, C.H. Marta, J.S. Mateus, A.G. Marjorie, C.L.A. Fernanda and M.A. Rogerio, 2014. Equine mesenchymal stem cells from bone 
marrow, adipose tissue and umbilical code: immunophenotypic characterization and differentiation potential. Stem cell Res. Ther., 5(25):1-11

Beaulah, J.V., S. Ushakumary, T.A. Kannan, B. Justin William, Geetha Ramesh, M. Parthiban and A. Raja, 2017.Culture and expansion of adipose derived mesenchymal stem cells in ovine. Indian J. Anim. Res., 51 (2): 340-343

Beaulah, J.V., S. Ushakumary, T.A.Kannan, B. Justin William and Geetha Ramesh, 2016. Isolation and Characterization of Adipose derived Mesenchymal Stem cells (ADMSCs) in Madras Red Sheep (Ovis aries). Adv. Biomed. Pharma., 3(3): 156160.

Bunnell, B.A., M. Flaat, C. Gagliardi, B. Patel and C. Ripoll. 2008. Adipose-derived stem cells: Isolation, expansion and differentiation. Science direct Methods.45: 115-120.

Deans, R.J and A. B. Moseley, 2000. Mesenchymal stem cells; Biology and potential clinical uses. Exp. Hematol., 28:875-884

Dominici, M., K.Le Blanc, I. Mueller, I. SlaperCortenbach, F. Marini, D. Krause, R. Deans, A. Keating, D. Prockop and E. Horwitz, 2006. Minimal criteria for defining multipotent mesenchymal stromal cells. The International Society for Cellular Therapy position statement. Cytotherapy. 8: 315-317.

Fadel, L., B. R. Viana, M. L. T. Feitosa, A. C. M. Ercolin, K. C. S. Roballo, J. B. Casals, N. C. G. Pieri, F. V. Meirelles, D. dos S. Martins, and M.A. Miglino, 2011. Protocols for obtainment and isolation of two mesenchymal stem cell sources in sheep. Acta Cir. Bras., 26 (4): 267-273

Hepsibha, P., T.V Meenambigai, A. Mangalagowari, A. Palanisamy, A. Stalin, S. Nithya and K. Kumanan, 2011.
Multipotent differentiation potential of buffalo adipose tissue derived mesenchymal stem cells. Asian J. Anim. Vet. Adv., 6(8): 772-788.

Kono, S., T. Kazama, K. Kano, K, Harada, M. Uechi and T. Matsumoto, 2014. Phenotypic and functional properties of feline dedifferentiated fat cells and adiposederived stem cells. Vet. J., 199: 88-96.

Marappagoundar, D., S. Indumathi, S. Rajkumar, V. Pachaiyappan, G.S. Kumar, V. Vidya and D. Suvdarsanum. 2010. Characterization of human adipose tissue derived hematopoietic stem cell, mesenchymal stem cell and side population cells. International J. Biol., 2(1): 71-78.

Neupane, M., C.C, Chang, M. Kiupel and V. Yuzbasiyan-Gurkan, 2008. Isolation and characterization of canine adipose-derived mesenchymal stem cells. Tissue Eng. Part A., 14(6):1007-1015

Ren.Y, H. Wua, X. Zhou, J. Wena, M. Jin, M. Cang, X. Guo, Q. Wang, D. Liu and Y. Mab, 2012. Isolation, expansion, and differentiation of goat adipose-derived stem cells. Res. Vet. Sci., 93: 404-411.

Vieira, N.M, V. Brandalise, E. Zucconi, M. Secco, B. E. Strauss and M. Zatz, 2010. Isolation, Characterization, and Differentiation Potential of Canine Adipose-Derived Stem Cells. Cell Transplant. 19: 279-289.

Webb, T.L., J.M. Quimby, and S.W Dow, 2011. In vitro comparison of feline bone marrowderived and adipose tissue-derived mesenchymal stem cells. J. Feline Med. Surg., 14(2): 165-168.

Zahran. F., I.M. El-Deen, S. Hamed and A.ELShenawy, 2013. Characterization of Adipogenic Differentiation of Mesenchymal Stem Cell Derived from Mice Adipose Tissue. Ind. J. Applied Research. 3: 18-22.

\section{How to cite this article:}

Shazia Nissar, Geetha Ramesh, Sabiha Hayath Basha, C. Balachandran and Leela, V. 2018. Isolation of Feline Adipose Tissue Derived Mesenchymal Stem Cells. Int.J.Curr.Microbiol.App.Sci. 7(03): 553-557. doi: https://doi.org/10.20546/ijcmas.2018.703.066 